\title{
SUMBER DAN INSPIRASI BELAJAR DALAM \\ PENGEMBANGAN PENDIDIKAN KARAKTER ANAK USIA DINI
}

\author{
Oleh \\ Ida Ayu Putu Utami Dewi', I Wayan Suyanta ${ }^{2}$ \\ 'PAUD PRA KUMARA DHARMA KERTI LUKLUK \\ ${ }^{2}$ DOSEN IHDN Denpasar \\ tamilukluk@gmail.com \\ suyanta.kaler@gmail.com
}

\begin{abstract}
Have we become inspirational teachers? Why should be an inspirational teacher? Have our students answered "Master is inspiration" when someone asks "children, what do you think about your teacher?" Good teachers who inspire teachers for learners, for example, advice, build learners to learn fun not stress and children are not afraid. Professional teachers should be able to educate children to be brave. Learning resources, all sources either in the form of data, people and certain forms that can be driven learners. Inspiration is interpreted with creative ideas that arise from within the self after an external stimulus. Therefore, teachers should be able to become "stimulants" for their students, inspiring for inspiration so that children can always be encouraged to bring up ideas, ideas, thoughts, actions, values, and positive creativity. Learning is the most priority activity in school activities. In the learning activities, the teacher is like a captain who controls the pace of the learning process in the classroom. In this learning process, teachers are required to be able to plan, design and implement approach / learning model using the method until the proper learnin media. The principles of APE are principles of productivity, creativity, activity, effective and efficient, and interesting and fun. From a material perspective, APE must be able to develop thinking power (cognition), rapid power, language, motor and skill aspects. Through tools used as a means of play, so that the child is expected to develop the function of intelligence, emotion and spiritual so that emerging intelligence that skyrocketed.
\end{abstract}

\section{Keywords: My Teacher Inspiration, My Student Source}

\begin{abstract}
Abstrak
Sudahkah kita menjadi guru inspiratif? Mengapa harus menjadi guru inspiratif? Sudahkah siswa kita akan menjawab "Guru adalah inspirasi" ketika ada orang yang bertanya tentang "Nak, bagaimana pendapatmu tentang gurumu?"Guru yang baik guru yang menginspirasi untuk peserta didik, sebagai teladan, contoh, nasehat membangun peserta didik agar belajar menyenangkan tidak tertekan dan anak tidak takut. Guru profesional harus dapat mendidik anak menjadi berani. Sumber belajar, semua sumber baik berupa data, orang dan wujud tertentu yang dapat digerak peserta didik. Inspirasi dimaknai dengan gagasan-gagasan kreatif yang muncul dari dalam diri setelah ada rangsangan dari luar. Maka dari itu, guru harus bisa menjadi "perangsang" bagi siswanya, memberi inspirasi demi inspirasi agar anak senantiasa dapat terdorong untuk memunculkan ide, gagasan, pemikiran, tindakan, nilai, hingga kretifitas yang positif. Belajar merupakan kegiatan paling prioritas dalam aktifitas di sekolah. Dalam kegiatan pembelajaran, guru bagaikan nahkoda yang mengontrol laju proses pembelajaran di kelas. Dalam proses pembelajaran ini, guru dituntut untuk bisa merencanakan, merancang hingga melaksanakan pendekatan/model pembelajaran menggunakan metode hingga media pembelajaran yang tepat.
\end{abstract}


Prinsip-prinsip APE merupakan prinsip produktifitas, kreatifitas, aktifitas, efektif dan efisien, serta menarik dan menyenangkan. Dari sudut pandang materinya, APE harus mampu mengembangkan daya pikir (kognisi), daya cepat, aspek bahasa, motorik dan ketrampilan. Melalu alat yang digunakan sebagai sarana bermain, sehingga anak diharapkan mampu mengembangkan fungsi intelegensinya, emosi dan spiritual sehingga muncul kecerdasan yang melejit.

\section{Kata Kunci: Guruku Inspirasiku, Siswa Sumber Belajarku}

\section{PENDAHULUAN}

Pendidikan Karakter bangsa merupakan bagian integrasi dari sistem pendidikan nasional harus dikembangkan dan dilaksanakan secara sistematik dan holistik .Upaya pembentukan karakter bangsa harus dimulai sejak dini karena usia dini adalah masa-masa yang paling kritis dalam peletakan fondasi pendidikan karater .Apabila pada saat usia dini peserta didik mendapatkan pendidikan yang tidak tepat ,akan menyulitkan pada tahaptahap selanjutnya. Maria Montessori, usia dini merupakan masa kritis dalam perkembangan anak, pada masa ini seluruh instrumen besar manusia terbentuk,yang meliputi seluruh potensi yang dimiliki anak,termasuk potensi pembentukan karakter.Bermain adalah kegiatan yang ditujukan untuk mendapatkan kesenangan .Bermain bagi anak-anak membantu mereka memahamidan mempraktekan kemampuan pengembangn rasa intelektual, sosial, danketerampilan sosial. Bermain bagi anak yang menyenagkan dengan penetrasi edukasi lewat permainan, termasuk nilai-nilai agama. Mengembangkan kreativitas pada anak adalah memunculkan sesuatu yang baru tanpa ada contoh sebelumnya.Oleh karena itu,suatu produk yang dikategorikan kreatif akan memenuhi sifat-sifat baru dan unik pada formasi finalnya,meskipun unsur-unsur dasar memang sudah ada sebelumnya .Kata kreatif merupakan kata berasal dari bahasa inggris To Create yang berarti mencipta,dan kreativitas adalah kemampuan untuk mencipta.Supriadi (dalam Rachmawati,2010)

Menyatakan kreativitas adalah kemampuan sesorang untuk melakukan sesuatu baru ,baik berupa gagasan maupun karya nyata,yang relatif berbeda dengan yang telah ada.Inspirasi adalah segala sesuatu yang dapat mendorong dan merangsang pikiran untuk memunculkan ide/gagasan maupun melakukan tindakan setelah melihat atau mempelajari sesuatu yang ada di sekitar. Inspirasi juga bisa dimaknai dengan gagasan-gagasan kreatif yang muncul dari dalam diri setelah ada rangsangan dari luar. Maka dari itu, guru harus bisa menjadi "perangsang" bagi siswanya, memberi inspirasi demi inspirasi agar anak senantiasa dapat terdorong untuk memunculkan ide, gagasan, pemikiran, tindakan, nilai, hingga kretifitas yang positif. Berkarya dan berkreasi. Itulah salah satu indicator pribadi unggulan dalam mendidik dan mengajar, beberapa contoh konkret yang bisa guru lakukan untuk menginspirasi siswa dalam Berkarya dan Berkreasi antara lain sebagai berikut.

- Merancang dan melaksanakan kegiatan pembelajaran yang 
memberi ruang siswa untuk mengembangkan kreatifitasnya.

- Melaksanakan kegiatan-kegiatan yang menekankan pada pembuatan proyek. Hal ini akan menuntut kreatifitas siswa.

- Guru harus senatiasa menciptakan inovasi demi inovasi dalam pembelajaran. Semangat pembaharuan yang ditunjukkan oleh guru akan bisa memicu semangat siswa untuk menciptakan hal baru sesuai dengan potensinya masing-masing.

- Guru bisa menampilkan ceritacerita inspiratif tentang tokohtokoh yang memiliki karya yang banyak sesuai bidangnya.

- Guru memberi kebebasan kepada anak ketika membuat karya dalam proses pembelajaran.

Upaya pengembangan alat permainan edukatif (APE) dapat dilakukan secara baik dan optimal maka Orangtua, Pendidik, Pengasuh/ perawat, Lembaga Pendidikan Anak Usia Dini (PAUD), diberikan pengetahuan tentang cara pembuatan dan penggunaan alat permainan edukatif (APE) Tradisional dan atau APE sederhana. Alat Permainan Edukatif Tradisional, dan atau Sederhana yang dapat dibuat sendiri dari bahanbahan yang ada di lingkungan rumah, limbah, bahan/alat yang sudah tidak dipakai lagi, atau bahan-bahan yang mudah didapat dalam rumahtangga atau sekitarnya.

\section{PEMBAHASAN}

Inspirasi adalah segala sesuatu yang dapat mendorong dan merangsang pikiran untuk memunculkan ide/gagasan maupun melakukan tindakan setelah melihat atau mempelajari sesuatu yang ada di sekitar. Inspirasi juga bisa dimaknai dengan gagasan-gagasan kreatif yang muncul dari dalam diri setelah ada rangsangan dari luar. Maka dari itu, guru harus bisa menjadi "perangsang" bagi siswanya, memberi inspirasi demi inspirasi agar anak senantiasa dapat terdorong untuk memunculkan ide, gagasan, pemikiran, tindakan, nilai, hingga kretifitas yang positif.

Karakter menjadi satu aspek yang sangat di prioritas.

- Guru harus selalu bersikap sabar dan ramah dalam bersosialisasi baik dengan siswa maupun yang lainnya.

Guru harus bisa menunjukkan bahwa guru adalah seorang yang taat beribadah.

Guru harus selalu bersikap jujur dan apa adanya. Tak masalah menjawab "belum tahu" apabila ada pertanyaan dari siswa yang memang guru belum tahu jawabannya.

- Guru harus senantiasa bersikap baik dan murah senyum pada siapa saja. Tak masalah bagi guru untuk lebih dahulu menyapa atau melempar senyum kepada muridnya.

Guru harus menunjukkan sikap mau bekerja sama. Tak masalah bagi guru untuk ikut membantu menyapu kelas, menutup jendela 
ataupun sekedar mematikan kipas angin.

- Guru harus senantiasa bersemangat dalam kondisi apa saja. Tak perlu memilkirkan masalah luar sekolah ketika sedang berada di tengahtengah siswa.

- Guru harus senantiasa bisa menjaga penampilan. Guru yang selalu terlihat bersih dan rapi akan bisa mendorong siswanya untuk berpenampilan bersih dan rapi pula.

Itulah beberapa contoh konkret Inspirasi guru untuk muridnya dalam hal karakter. Dan karakter pada intinya adalah suatu hal yang membudaya dan menjadi sebuah kebiasaan tanpa adanya paksaan. Karena itu dalam penanamannya hanya perlu pembiasaan. Diulang dan terus diulang dalam mengajak dan memberi arahan. Dan konsisten dalam menunjukkan keteladanan.

Belajar merupakan kegiatan paling prioritas dalam aktifitas di sekolah. Dalam kegiatan pembelajaran, guru bagaikan nahkoda yang mengontrol laju proses pembelajaran di kelas. Dalam proses pembelajaran ini, guru dituntut untuk bisa merencanakan, merancang hingga melaksanakan pendekatan/model pembelajaran menggunakan metode hingga media pembelajaran yang tepat.

Kaitannya dengan inspirasi dalam belajar, apakah setiap model pembelajaran yang diterapkan guru pasti akan menginspirasi siswanya? Apakah setiap metode yang dipakai sudah pasti bisa menginspirasi siswa? Apakah setiap media pembelajaran yang digunakan siswa memberi garansi siswa akan terinspirasi?

Berikut ini beberapa kunci yang harus diperhatikan guru agar proses pembelajaran yang diterapkan benar-benar memberi inspirasi siswa untuk terus belajar, mengembangkan kemampuannya, mengubah pola pikirnya atau bahkan mengubah kebiasaan/sikap. Proses pembelajaran yang dilakukan dapat menarik antusiasme siswa, sehingga focus belajar dan keigintahuan siswa pun terus muncul selama proses belajar.

a) Guru merancang pembelajaran yang memungkinkan siswa merasa senang dan nyaman dalam proses pembelajaran, sehingga siswa mudah untuk mengikuti setiap langkah kegiatan yang disusun oleh guru.

b) Guru memunculkan sebuah scenario pembelajaran yang bisa menjadi "unforgettable moment" bagi siswa. Sehingga pembelajaran yang dilaksanakan melekat dalam waktu jangka panjang di ingatan siswa.

c) Guru menerapkan "meaningfull learning” / pembelajaran bermakna yang mana setiap muatan materi baru dikaitkan dengan pemahaman dan pengalaman belajar siswa sebelumnya. Dengan begitu siswa akan mudah untuk mengkonstruksi pengetahuan yang sudah melekat di memorinya dan pengetahuan baru yang sedang dikuasainya.

d) Guru menerapkan pendekatan, model, metode hingga media pembelajaran yang bervariasi 
di setiap proses pembelajaran. Hal ini penting dilakukan karena proses pembelajaran yang statis akan memunculkan rasa bosan pada diri siswa. Kebosanan untuk mengikuti proses pembelajaran dapat menghambat semangat dan perkembangan belajar siswa.

e) Guru memperhatikan gaya belajar siswa dan memfasilitasinya. Sebagai guru kita harus bisa memfasilitasi semua karakteristik gaya belajar siswa. Gaya belajar bisa dibedakan menjadi gaya belajar tipe auditori, visual, maupun kinestetik. Dan guru harus bisa memvariasikan pembelajaran dengan memuat 3 gaya belajar tersebut. Sehingga semua siswa merasa terfasilitasi dalam proses pembelajaran.

f) Guru sebagai "figur teladan dalam belajar". Guru harus senantiasa semangat untuk meng-upgrade diri dengan terus belajar. Bisa dibayangkan apabila guru saja tidak mau belajar, bagaimana dengan siswanya? Maka dari itu guru harus selalu menjadi pribadi pembelajar, terus belajar.

Berkarya dan berkreasi. Itulah salah satu indicator pribadi unggulan dalam mendidik dan mengajar, beberapa contoh konkret yang bisa guru lakukan untuk menginspirasi siswa dalam Berkarya dan Berkreasi antara lain sebagai berikut.

- Merancang dan melaksanakan kegiatan pembelajaran yang memberi ruang siswa untuk mengembangkan kreatifitasnya.
Melaksanakan kegiatan-kegiatan yang menekankan pada pembuatan proyek. Hal ini akan menuntut kreatifitas siswa.

- Guru harus senatiasa menciptakan inovasi demi inovasi dalam pembelajaran. Semangat pembaharuan yang ditunjukkan oleh guru akan bisa memicu semangat siswa untuk menciptakan hal baru sesuai dengan potensinya masing-masing.

- Guru bisa menampilkan ceritacerita inspiratif tentang tokohtokoh yang memiliki karya yang banyak sesuai bidangnya.

- Guru memberi kebebasan kepada anak ketika membuat karya dalam proses pembelajaran.

Upaya pengembangan alat permainan edukatif (APE) dapat dilakukan secara baik dan optimal maka Orangtua, Pendidik, Pengasuh/ perawat, Lembaga Pendidikan Anak Usia Dini (PAUD), diberikan pengetahuan tentang cara pembuatan dan penggunaan alat permainan edukatif (APE) Tradisional dan atau APE sederhana. Alat Permainan Edukatif Tradisional, dan atau Sederhana yang dapat dibuat sendiri dari bahanbahan yang ada di lingkungan rumah, limbah, bahan/alat yang sudah tidak dipakai lagi, atau bahan-bahan yang mudah didapat dalam rumahtangga atau sekitarnya.

\section{Konsep Alat Permainan Edukatif}

Alat Permainan Edukatif (APE) adalah sarana untuk merangsang anak 
dalam mempelajari sesuatu tanpa anak menyadarinya, baik menggunakan teknologi moderen, konvensional maupun tradisional. Latar belakang dibuatnya APE adalah sebagai upaya merangsang kemampuan fisik motorik anak (aspek psikomotor), kemampuan sosial emosional (aspekafektif) serta kemampuan kecerdasan (kognisi).

Prinsip-prinsip APE merupakan prinsip produktifitas, kreatifitas, aktifitas, efektif dan efisien, serta menarik dan menyenangkan. Dari sudut pandang materinya, APE harus mampu mengembangkan daya pikir (kognisi), daya cepat, aspek bahasa, motorik dan ketrampilan. Melalu alat yang digunakan sebagai sarana bermain, sehingga anak diharapkan mampu mengembangkan fungsi intelegensinya, emosi dan spiritual sehingga muncul kecerdasan yang melejit.

Alat permainan yang baik diharapkan mampu menjadi sarana yang dapat mendorong anak bermain bersama, mengembangkan daya fantasi, multi fungsi, menarik, berukuran besar dan awet, tidak membahayakan, disesuaikan dengan kebutuhan, desain mudah dan sederhana, serta bahan-bahan yang digunakan murah dan mudah diperoleh.

Pembuatan APE yang baik mampu mengembangkan totalitas kepribadian anak, bukan karena kebagusannya, tetapi karena aspek kreatifitasnya, sehingga mampu menjadi sarana bermain yang aktif, menarik, menyenangkan dan bermanfaat.
Beberapa fungsi APE antara lain :

a. Mengajar menjadi lebih mudah dancepat diterima anak

b. Melatih konsentrasi anak

c. Mampu mengatasi keterbatasan waktu dan tempat

d. Membangkitkan emosi

e. Menambah daya ingat

f. Menjamin atmosfir pembelajaran yang kondusif

Dalam memilih alat dan perlengkapan bermain dan belajar anak untuk kreatif anak, guru dan orang tua sebaiknya memperhatikan ciri-ciri peralatan yang baik. Ciri-ciri peralatan yang baik di antaranya:

1. Desain Mudah dan Sederhana

Pemilihan alat untuk kegiatan kreativitas anak sebaiknya memilih yang sederhana dari segi desainnya. Karena jika peralatan terlalu banyak detail (rumit) akan menghambat kebebasan anak untuk berkreasi. Yang terpenting adalah alat tersebut tepat dan mengena pada sasaran edukatif, sehingga anak tidak merasa terbebani oleh kerumitannya.

2. Multifungsi (Serba Guna)

Peralatan yang diberikan kepada anak sebaiknya serba guna, sesuai untuk anak laki-laki maupun anak perempuan. Selain itu, alat kreativitas juga dapat dibentuk sesuai dengan daya kreativitas dan keinginan anak.

3. Menarik

Sebaiknya pilihlah peralatan yang memungkinkan dan dapat 
memotivasi anak untuk melakukan berbagai kegiatan serta tidak memerlukan pengawasan terusmenerus, atau penjelasan panjang lebar mengenai penggunaannya. Dengan demikian anak akan bebas dengan penuh kesukaan dan kegembiraan dalam mengekspresikan kegiatan kreatifnya.

4. Berukuran Besar

Alat kreativitas yang berukuran besar akan memudahkan anak untuk memegangnya. Anak-anak dalam fase anal biasanya semua yang dapat dijangkau dan dipegang lalu dimasukkan ke mulutnya. Untuk menghindari kemungkina yang membahayakan, maka sebaiknya memilih peralatan yang berukuran besar.

5. Awet

Biasanya, peralatan yang tahan lama harganya lumayan mahal. Namun demikian, tidak semua peralatan yang tahan lama harganya lebih mahal. Ciri dari bahan yang tahan lama adalah tidak pegas, lentur, keras dan kuat.

6. Sesuai Kebutuhan

Sedikit banyaknya peralatan yang digunakan tergantung seberapa banyak kebutuhan anak akan peralatan tersebut.

7. Tidak Membahayakan

Tingkat keamanan suatu peralatan kreativitas anak sangat membantu orang tua atau pendidik dalam mengawasi anak. Karena banyak alat yang dapat menimbulkan kekhawatiran jika anak menggunakannya, seperti; pisau, cutter, jarum, peralatan kecil, dan lain sebagainya.

8. Mendorong Anak untuk Bermain Bersama

Untuk mendorong anak dapat bermain bersama, maka diperlukan alat yang dapat merangsang kegiatan yang melibatkan orang lain. Oleh karenya, orang tua sebaiknya memberi kesempatan pada anak untuk bersosialisasi dengan teman sebayanya untuk bermain dengan segenap kreativitas positifnya. Contoh alat yang cukup membantu anak bersosialisasi adalah rumah-rumahan atau tenda yang sedikitnya dapat menampung minimal dua anak, pistol-pistolan dan bola.

9. Mengembangkan Daya Fantasi Alat permainan yang sifatnya mudah dibentuk dan diubahubah sangat sesuai untuk mengembangkan daya fantasi anak, karena memberikan kesempatan pada anak untuk mencoba dan melatih daya fantasinya.

10. Bukan Karena Kelucuan dan Kebagusannya

Alat-alat yang dipilih sebagai alat pengembangan kreativitas anak bukan sekedar alat yang bagus atau lucu. Akan tetapi alat permainan yang mampu mengembangkan intelektualitas, afeksi, dan motorik anak. 
11. Bahan Murah dan Mudah Diperoleh Kebanyakan orang tua lebih menyukai peralatan kreativitas yang harganya cukup mahal. Karena ada image bahwa peralatan yang mahal adalah peralatan yang berkualitas dan bagus. Peralatan yang mahal tersebut dianggap benar-benar dapat meningkatkan perkembangan kreativitas anak.

\section{Kriteria Pemilihan Alat Permainan Edukatif}

Sebelum membuat alat permainan edukatif, guru harus memperhatikan terlebih dulu beberapa persyaratan pembuatannya. Persyaratan tersebut meliputi syarat edukatif, syarat teknis dan syarat estetika. Adapun syarat-syarat APE adalah sebagai berikut :

1. Syarat edukatif

a) Ape di buat disesuaikan dengan memperhatikan program kegiatan pendidikan (program pendidikan yang berlaku)

b) APE yang di buat disesuaikan dengan didaktik metodik yang artinya dapat membantu keberhasilan kegiatan pendidik mendorong aktifitas dan kreativitas anak sesuai dengan kemampuan (tahap perkembangan anak).

2. Syarat Teknis

a) APE di rancang sesuai dengan tujuan, fungsi sarana (tidak menimbulkan kesalahan konsep) contohnya dalam membuat balok bangunan, ketepatan bentuk dan ukuran yang akurat mutlak dipenuhi karena jika ukurannya tidak tepat akan menimbulkan kesalahan konsep.

b) APE hendaknya multi guna, walaupun ditujukan untuk tujuan tertentu tidak menutup kemungkinan digunakan untuk tujuan pengembangan yang lain.

c) APE di buat dengan menggunakan bahan yang mudah didapat dilingkungan sekitar, murah atau dari bahan bekas/sisa.

d) Aman (tidak mengandung unsure yang membahayakan anak misalnya tajam, beracun dli).

e) APE hendaknya awet, kuat dan tahan lama (tetap efektif walau cahaya berubah).

f) Mudah dalam pemakaian, menambah kesenangan anak untuk bereksperimen dan bereksplorasi.

g) Dapat digunakan secara individual, kelompok dan klasikal.

3. Syarat estetika
a) Bentuk yang elastis, ringan (mudah di bawa anak)
b) Keserasian ukuran (tidak terlalu besar atau terlalu kecil)
c) Warna (kombinasi warna) serasi dan menarik.


Prosedur pembuatan APE dapat dilakukan oleh guru melalui langkahlangkah sebagai berikut:

a) Guru mempelajari dan menguasai rencana program pendidikan terutama mengenai kemampuankemampuan yang harus di capai oleh anak.

b) Guru melakukan analisis program pendidikan dengan maksud mengetahui hubungan antara kemampuan yang akan di capai anak dengan jenis kegiatan yang akan di lakukan dan sarana yang diperlukan.

c) Menginvestarisasi sarana (alat permainan) yang ada.

d) Memeriksa kelengkapan alat menyangkut kelengkapan setiap jenis jenis dan jumlah yang diperlukan.

e) Memeriksa fungsi alat yang ada, apakah masih berfungsi dengan baik atau tidak.

f) Mengidentifikasi kebutuhan sarana yang diperlukan untuk melaksanakan kegiatan pembelajaran.

g) Merencanakan pembuatan APE

h) Melaksanakan pembuatan APE

Cara Membuat dan Memainkan Alat Permainan Edukatif serta Manfaatnya bagi Perkembangan Anak Usia Dini

1. Botol Angka

Botol angka adalah permainan yang mengenalkan kepada anak tentang lambag bilangan, warna serta jumlah banyak dan sedikit (mengenal aspek kognitif).
Alat dan bahan:

Bahan : botol bekas, lem, kertas warna, crayon dan biji.

Cara bermain:

Anak menulis angka 1-5 menggunakan crayon pada kertas warna kemudian ditempelkan pada botol, selanjutnya biji-biji tersebut dituangkan ke dalam botol sesuai dengan jumlah banyak sedikit dari lambang bilangan 1-5 berdasarkan jumlah biji yang dimasukkan ke dalam botol.

Manfaat permainan :

- $\quad$ NAM: Anak menjadi terlatih untuk sabar memainkan permainan ini

- Kognitif: Anak dapat mengenal lambang bilangan, mengenal nama warna serta membedakan jumlah banyak dan sedikit.

- Sosial: Anak dapat bekerja sama dengan temannya.

- Fisik-Motorik: Anak dapat melatih motorik halus dalam menulis angka pada kertas, menempelkannya dan menuangkan biji ke dalam botol.

- Bahasa: Anak dapat menyebutkan lambang bilangan 1-5 dan menyebutkan nama warna

- $\quad$ Seni: Anak dapat menetahui berbagai macam warna pada kertas dan crayon. 
2. Telur Pecah

Telur pecah adalah permainan yang dapat digunakan untuk mengembangkan kognitif anak dengan menghubungkan gambar dengan namanya.

Bahan:

- $\quad$ Sterofom, Gunting, Gambar buah, Lem, Jangka

Cara membuat:

1. Bentuk lingkaran pada sterofoam, kemudian gunting lingkaran tersebut.

2. Ditengah lingkaran, buat garis zig-zag menyerupai telur yang pecah dan potong hingga terbagi jadi dua.

3. Pada salah satu potongan, tempel gambar buah. Dan potongan yang lain tempelkan nama buah.

4. Suruh anak memainkan alat tersebut dengan menghubungkan dua potongan tersebut sesuai dengan nama dan gambarnya. Manfaat Permainan:

- Kognitif: Menghubungkan duabuahbenda, mencocokkan nama dengan gambar.

- Sosial-Emosional: Antusias dalam mengikuti permainan.

- Bahasa: Mengucapkan nama buah.

- $\quad \mathrm{F}$ i s i k-M o t orik: Menghubungkan dua buah benda.

\section{SIMPULAN}

Guru ispirasiku ,siswa sumber belajarku dengan bahan bekas sebagai pembuatan ape. Guru yang baik menginpirasi untuk peserta didik. Inspirasi sebagai teladan, contoh, nasehat, membangun peserta didik agar belajar menyenagkan tidak tertekan, dan anak tidak takut guru. Guru Profesional harus dapat mendidik anak menjadi berani. Sumber belajar semua dapat berupa bahan bekas yang ada dilingkugan sekitar sekolah, anak aktif melakukan dengan senang, menambah pengalaman dan merangsang perkembangan anak.

Alat permainan edukatif adalah alat yang dapat digunakan untuk bermain bagi anak yang didalamnya mengandung nilainilai edukatif. APE mampu menciptakan prinsip bermain sambil belajar dan belajar sambil bermain pada anak usia dini. Jadi, bermainnya anak memiliki nilai-nilai pembelajaran.

Selanjutnya, dalam memilih alat permainan untuk anak, orang tua atau pendidik sebaiknya memperhatikan beberapa prinsip APE (yang mencakup: prinsip produktivitas, prinsip aktivitas, prinsip kreativitas, prinsip efektifitas dan efisiensi serta prinsip mendidik yang menyenangkan) dan ciri-ciri alat permainan yang baik untuk anak (yang meliputi: Desain Mudah dan Sederhana, Multifungsi, menarik, awet, berukuran besar, tidak membahayakan, sesuai kebutuhan, barang murah dan mudah didapat, bukan karena kelucuan atau kebagusannya, mendorong anak untuk bermain bersama, serta dapat mengembangkan daya fantasi anak) 


\section{DAFTAR PUSTAKA}

1. https://gurudigital.id/menjadiguru-inspiratif-karena-guruadalah-inspirasi/

2. Martuti, A.2008. Mengelola PAUD dengan Aneka Permainan Meraih Kecerdasan Majemuk. Yogyakarta: Kreasi Wacana. 
FOTO KEGIATAN BERMAIN DENGAN BAHAN BEKAS

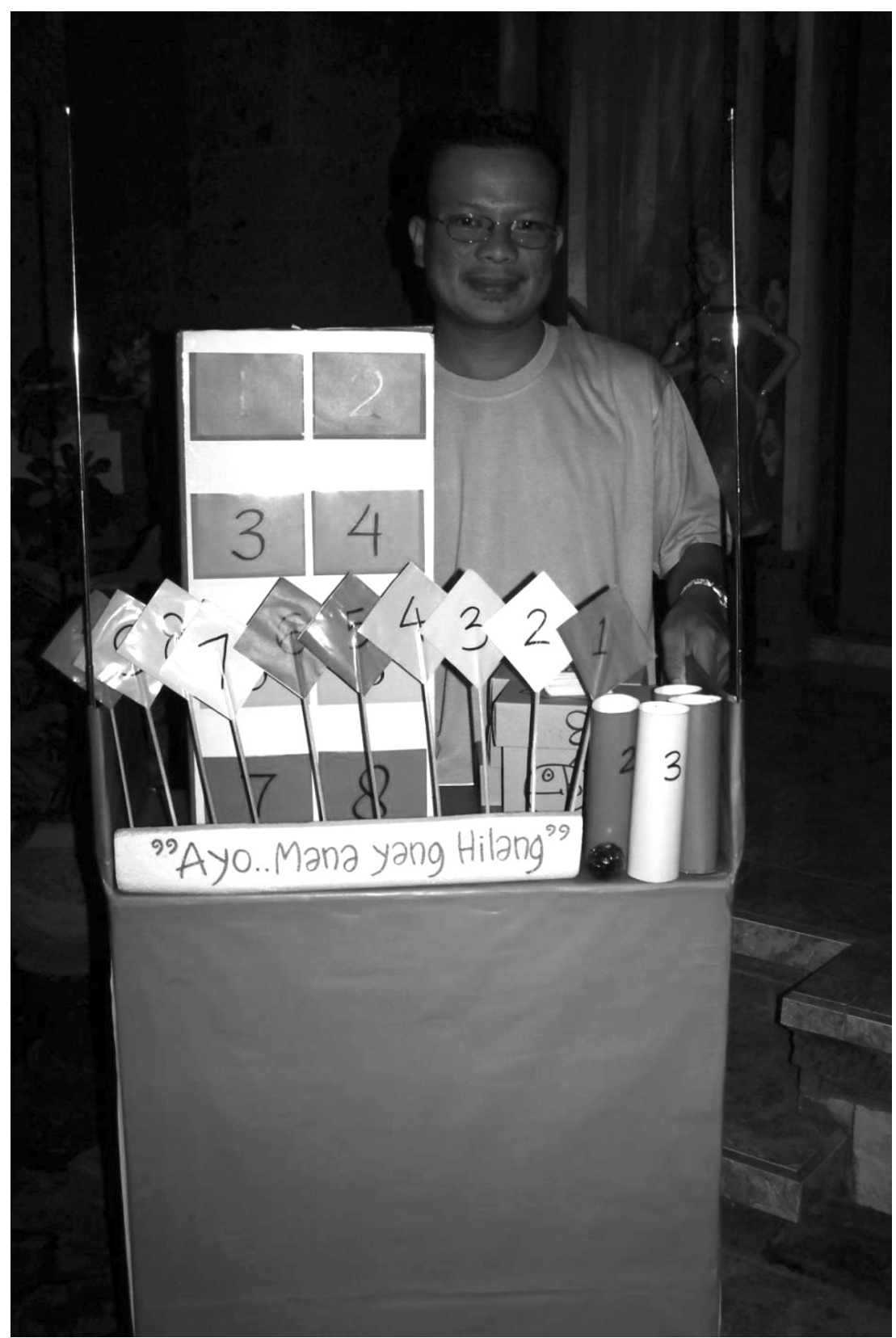



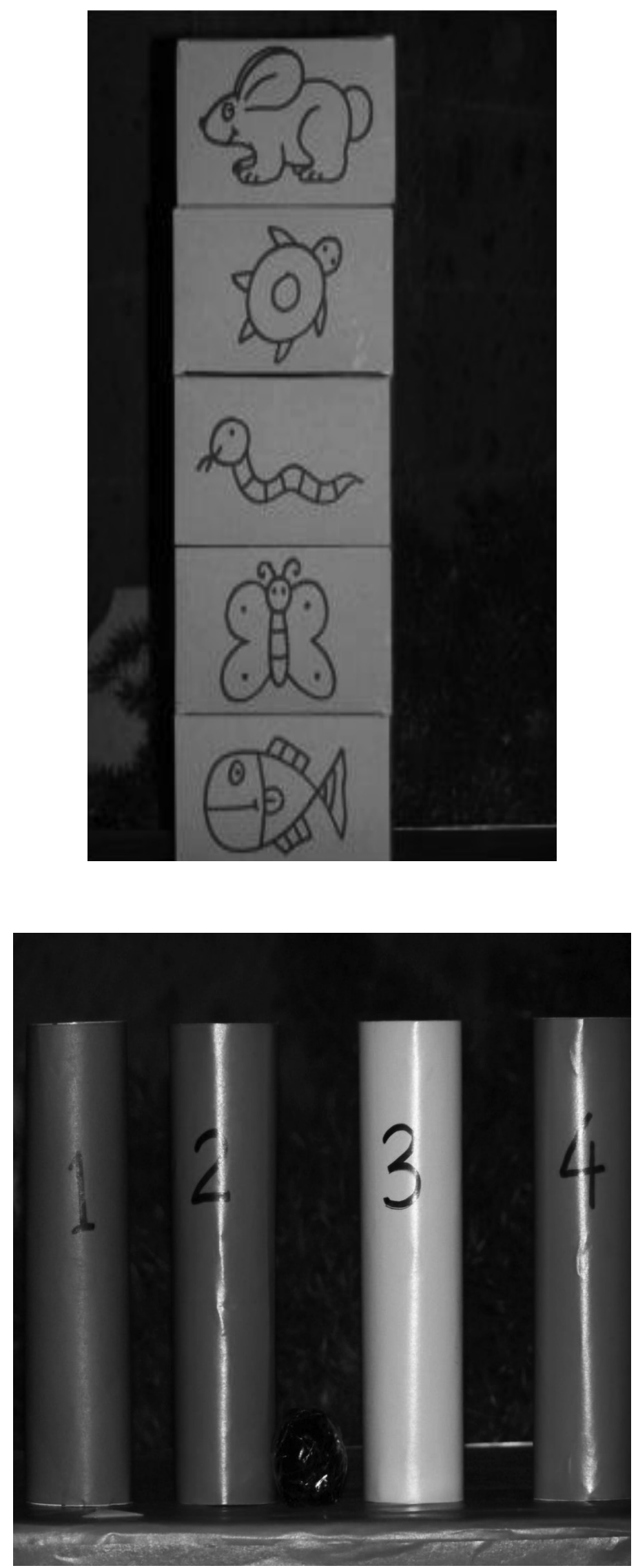

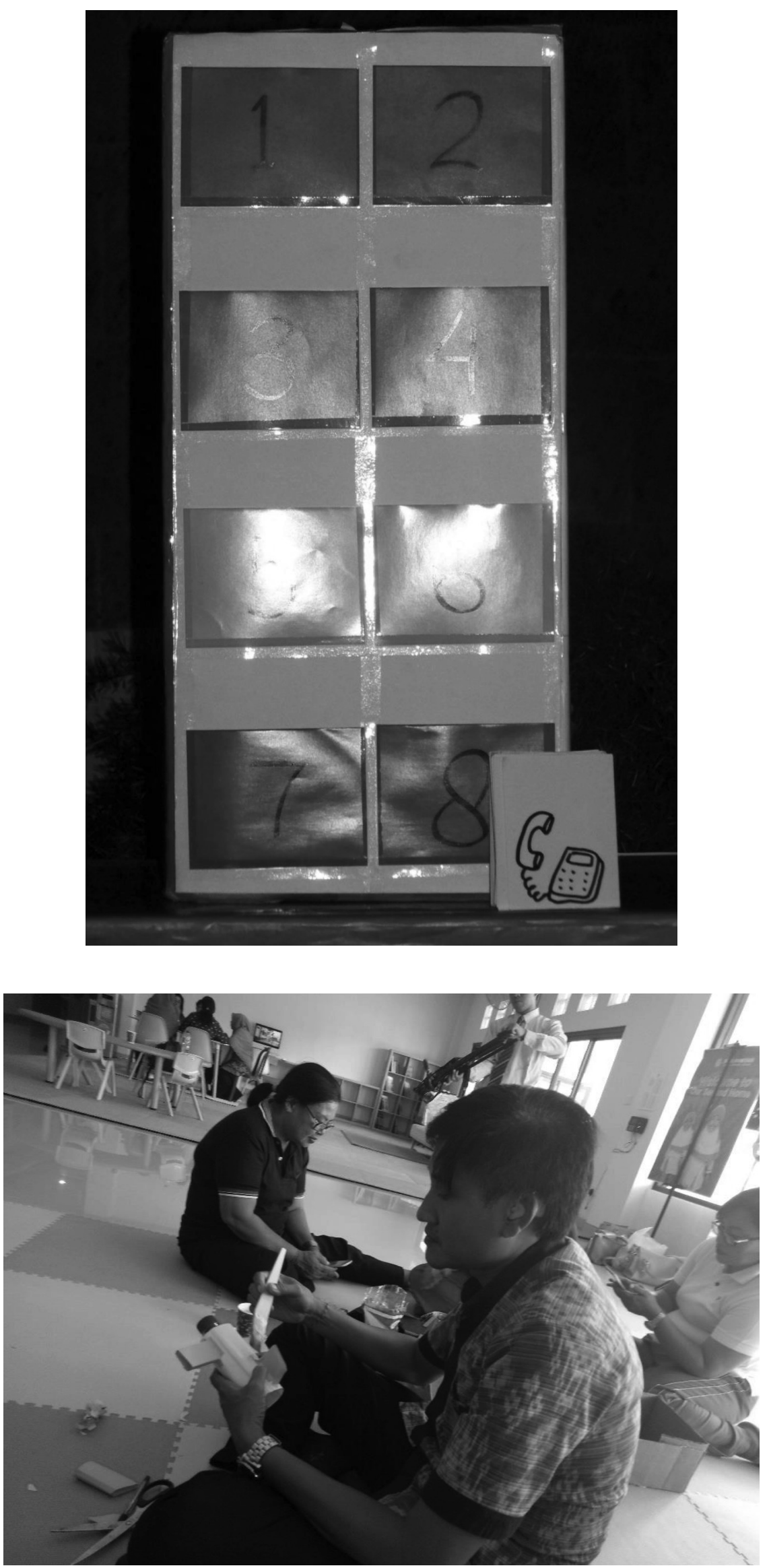

PRATAMA WIDYA, VOL. 3, NO. 1, 2018 


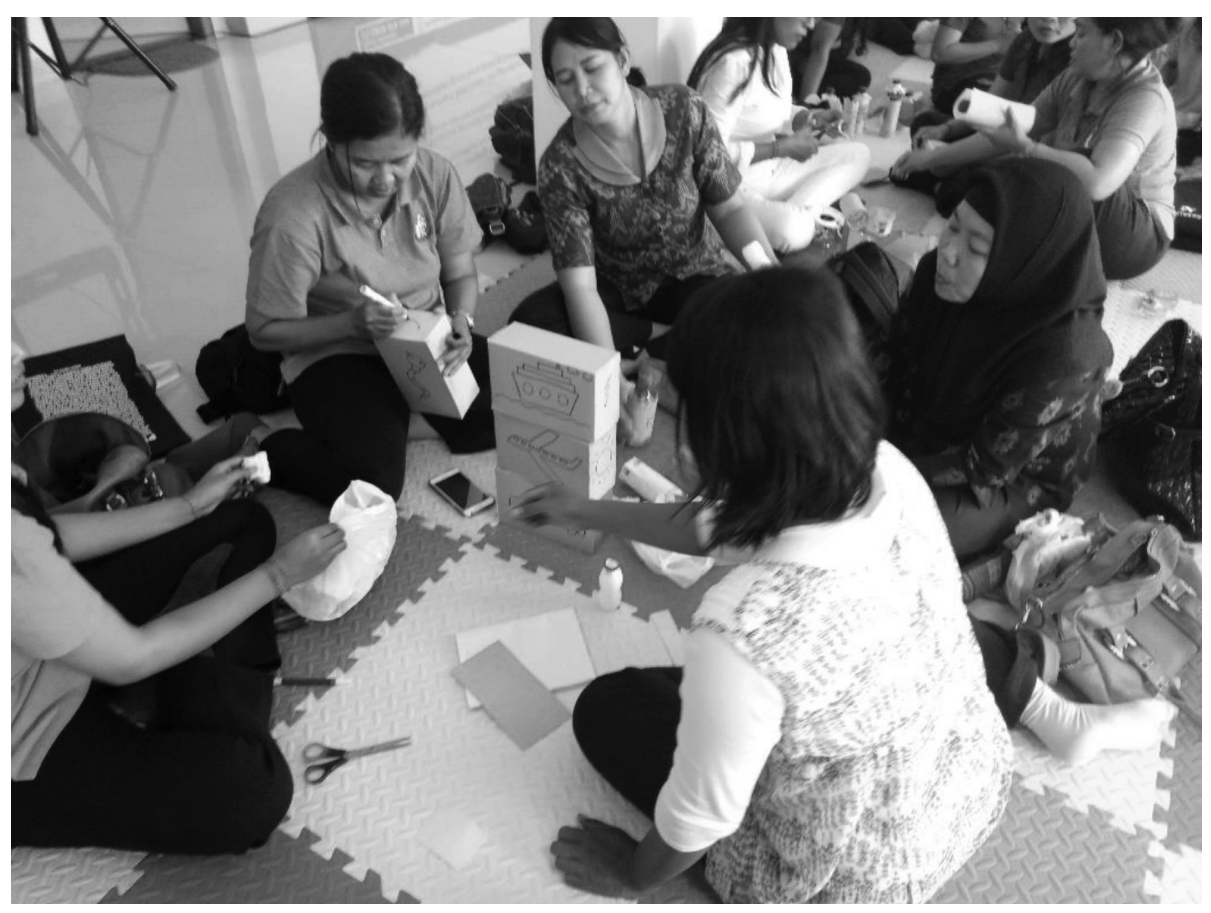

